\title{
ОПТИМІЗАЦІЯ СТИСНЕННЯ ТКАНИНИ ЯК УМОВА КОНТРОЛЬОВАНОЇ ЗМІНИ ІМПЕДАНСУ ПРИ СТВОРЕННІ ЕЛЕКТРОЗВАРНОГО МІЖКИШКОВОГО АНАСТОМОЗУ
}

\author{
С. С. Подпрятов ${ }^{1,2}$, Г. С. Маринський ${ }^{3}$ В. А. Ткаченко ${ }^{3}$, \\ О. В. Чернець ${ }^{3}$, К. Г. Лопаткіна ${ }^{3}$, \\ В. А. Васильченко ${ }^{3}$, Н. А. Чвертко \\ ${ }^{1}$ Київський міський центр електрозварювальної хірургії та новітніх хірургічних технологій \\ ${ }^{2}$ Київська міська клінічна лікарня № 1 \\ з/нститут електрозварювання ім. Є. О. Патона НАН України
}

Неоднорідність стінок кишок спричинює нерівномірність структури електрозварного з'єднання та, відповідно, потребу у посиленому стисненні задля гомогенізації щільності та електропровідності. Але при цьому величина стиснення є близькою до руйнівної для стінки кишки, оскільки менші величини є неесективними.

Мета: створити оптимальний засіб врівноваження та розподілу зусилля щодо стиснення тканини в моделі електрозварного міжкишкового анастомозу задля досягнення цим способом стабільності відпрацьовування алгоритму високочастотного зварювання стінок кишки.

Матеріал та методи. Здійснили 348 досліджень програмованого подавання на тканину органокомплексу свині радіочастотної електричної напруги до 200 В з контрольованою зміною імпедансу після прикладення на електроди

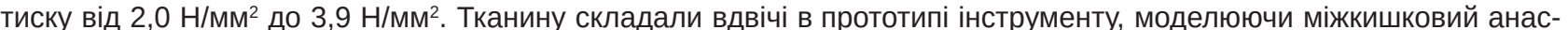

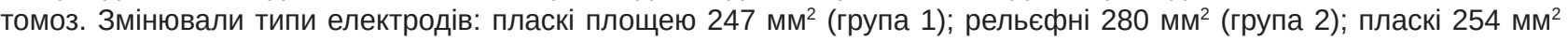
з обмежувачами їх зближення (група 3).

Результати. В групі 1 ми спробували, з кроком 0,1 Н/мм², підібрати величину тиску між електродами як точку рівноваги механічних та електричних властивостей. У 7,5\% досліджень спостерігали недосягнення базових параметрів, у 42,5\% - значне відхиленням швидкості зростання, у 7,5\% - критичне зниження імпедансу.

В групі 2 досліджували запобігання можливого зміщення електродів шляхом застосування різних консрігурацій рельєфу електродів. У цій серії досліджень зросла частота досягнення базових параметрів зниження імпедансу до $82,5 \%$, але в наступній фразі раптове падіння спостерігали у 30\% досліджень. Також у 32,5\% проб відбувалися значні коливання імпедансу. В групі 3 досліджували обмеження зближення електродів на відстані від 0,03 мм до 0,3 мм. Застосування обмежувачів виявилося найефективнішим при співвідношенні висоти обмежувача до товщини тканин між електродами в моделі анастомозу як 1:40. Критичне падіння імпедансу спостерігали лише в 2,5\% досліджень.

Висновки. Зменшення тиску електродів на тканину посилює відхилення величини імпедансу від цільової. Застосування їхньої рельєфної фрорми підвищує електропровідність і покращує стартову частину електрозварного впливу, але посилює нерівномірність в його кінцевій частині через фрлуктуацію імпедансу. Застосування обмежувачів зближення електродів забезпечує повнотривале відпрацювання алгоритму електрозварного впливу за всіх досліджених величин оптимального та субкритичного стиснення.

Обговорення та перспективи подальших досліджень. Отримані дані покликані слугувати основою технологічних рішень у створенні відповідних елементів робочої частини спеціалізованого інструменту для фоормування електрозварних анастомозів. Їх технологічне впровадження надасть можливість додатково наростити встановлені переваги електрозварного міжкишкового з'єднання над шовним. Цей технологічний засіб може також бути ефективним для підвищення ефрективності зварювання інших біологічних тканин.

Ключові слова: тиск, тканина, електричне зварювання, анастомоз, кишка, свиня, інструмент, імпеданс.

(c) С. С. Подпрятов, Г. С. Маринський, В. А. Ткаченко, О. В. Чернець, К. Г. Лопаткіна, В. А. Васильченко, Н. А. Чвертко 


\title{
THE TISSUE COMPRESSION OPTIMIZATION AS THE CONDITION OF CONTROLLED IMPEDANCE CHANGE DURING ELECTRIC WELDING INTESTINAL ANASTOMOSIS CREATING
}

\author{
S. S. Podpriatov ${ }^{1,2}$, G. S. Marinsky ${ }^{3}$, V. A. Tkachenko ${ }^{3}$, \\ O. V. Chernets ${ }^{3}$, K. G. Lopatkina ${ }^{3}$, \\ V. A. Vasylchenko ${ }^{3}$, N. A. Chvertko 3 \\ ${ }^{1}$ Clinical research centre of bonding/welding surgery and new surgical technologies \\ ${ }^{2}$ Kyiv municipal hospital clinic \#1 \\ ${ }^{3}$ E. O. Paton Electric welding institute of the National Academy of Science
}

Introduction. The intestinal wall' structural unevenness determines uneven structure of the electric welding compound, and, accordingly, needs for increased compression to homogenize the density and electrical conductivity for better connection result. But at the same time, the required compression amount is close to destructive for intestine wall, since smaller quantities are ineffective.

Aim: was to create the optimum method for balancing and distributing the compression effort on intestinal tissue in the model of electro-welded anastomosis in order to achieve by this way the high frequency welding process stability during the gut walls connecting.

Material and methods. We performed 348 studies of programmed influence to pig organ complex the radio frequency electric voltage up to $200 \mathrm{~V}$, with controlled change of impedance, after a pressure of $2.0 \mathrm{~N} / \mathrm{mm}^{2}$ to $3.9 \mathrm{~N} / \mathrm{mm}^{2} \mathrm{have}$ applied on electrodes. The intestines were doubled in the instrument prototype, simulating an anastomosis. Electrode types were changed: smooth $247 \mathrm{~mm}^{2}$ (group 1); relief $280 \mathrm{~mm}^{2}$ (group 2); smooth $254 \mathrm{~mm}^{2}$ included limiters of their approach (group 3).

Results. In group 1 we tried to find by the steps of $0.1 \mathrm{~N} / \mathrm{mm}^{2}$, the pressure value as a point of equilibrium of mechanical and electrical properties. In $7.5 \%$ studies the failure of basic impedance parameters achieving was observed, in $42.5 \%$ — significant deviation of growth rate, in $7.5 \%$ - its critical decrease. In group 2, the prevention of possible electrodes displacement was investigated by applying that's different relief configurations. In this series, the basic impedance reduction parameters achieving increased to $82.5 \%$, but in the next phase its sudden drop was observed in $30 \%$ probes. Also in $32.5 \%$ the significant impedance fluctuations were observed. In group 3, the electrodes approaching limitations in the range of $0.03 \mathrm{~mm}$ to $0.3 \mathrm{~mm}$ were studied. The limiters usage proved to be most effective at the ratio: limiter height to tissues thickness between the electrodes in anastomosis model — as 1:40. A critical impedance drop was observed in only $2.5 \%$ of studies.

Conclusions. The electrodes pressure reducing increases the tissues impedance deviation from the target. The relief electrodes increases electrical conductivity and improves the starting part of electric welding, but increases the unevenness in its end part due to the impedance fluctuation. The limiters of electrodes approach usage provide the effect of full-time electric welding algorithm elaboration, regardless the values of optimal or subcritical intestinal compression.

Discussion. The obtained data are intended to serve as the technological solutions basis in creating the elements of the specialized electric weld anastomosis making tool. Their technological introduction will provide the further increase of yet established benefits of electric-welded anastomosis over sewn and stapled. This technological device could be also effective in other biological tissues welding.

Key words: pressure, tissue, electric welding, anastomosis, intestine, pig, instrument, impedance. 


\title{
ОПТИМИЗАЦИЯ СЖАТИЯ ТКАНЕЙ КАК УСЛОВИЕ КОНТРОЛИРУЕМОГО ИЗМЕНЕНИЯ ИМПЕДАНСА ПРИ СОЗДАНИИ ЭЛЕКТРОСВАРНОГО МЕЖКИШЕЧНОГО АНАСТОМОЗА
}

\author{
С. С.Подпрятов ${ }^{1,2}$, Г. С. Маринский ${ }^{3}$ В. А. Ткаченко ${ }^{3}$, \\ А. В. Чернец ${ }^{3}$, Е. Г. Лопаткина ${ }^{3}$, \\ В. А. Васильченко ${ }^{3}$, Н. А. Чвертко \\ ${ }^{1}$ Киевский городской центр электросварочной хирургии и новых хирургических технологий \\ ${ }^{2}$ Киевская городская клиническая больница № 1 \\ Зинститут электросварки им. Е. О. Патона НАН Украины
}

\begin{abstract}
Неоднородность стенок кишки определяет неравномерность структуры электросварочного соединения, и, соответственно, потребность в усиленном сжатии для гомогенизации плотности и электропроводности. Но при этом величина сжатия близка к разрушительной для стенки кишки, поскольку меньшие величины являются неэффективными. Цель: создать оптимальное средство уравновешивания и распределения усилия по сжатию ткани в модели электросварного межкишечного анастомоза для достижения этим способом стабильности отработки алгоритма высокочастотной сварки стенок кишки.

Материал и методы. Осуществили 348 исследований программированной подачи на ткань органокомплекса свиньи радиочастотного электрического напряжения до 200 В с контролируемым изменением импеданса, после при-

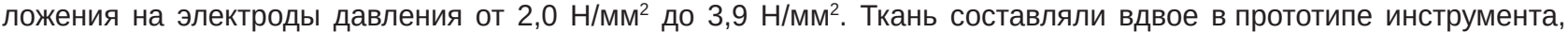

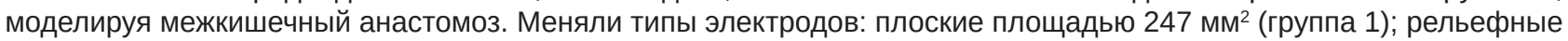

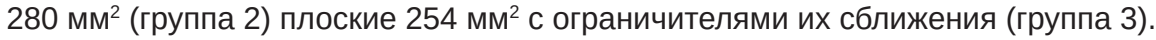


точку равновесия механических и электрических свойств. В 7,5\% исследований наблюдали недостижение базовых параметров, в 42,5\% - значительное отклонение скорости подъема, в 7,5\% - критическое снижение импеданса. В группе 2 исследовали предотвращение возможного смещения электродов путем применения различных конфригураций рельефа электродов. В этой серии исследований возросла частота достижения базовых параметров снижения импеданса до 82,5\%, но в следующей сразе внезапное падение наблюдали в 30\% исследований. Также в 32,5\% проб происходили значительные колебания импеданса. В группе 3 исследовали ограничение сближения электродов на расстояние от 0,03 мм до 0,3 мм. Применение ограничителей оказалось эсрфективным при соотношении высоты ограничителя к толщине тканей между электродами в модели анастомоза как 1:40. Критическое падение импеданса наблюдали лишь в 2,5\% исследований.

Выводы. Уменьшение давления электродов на ткань усиливает отклонение величины импеданса от целевой. Применение их рельефной фрормы повышает электропроводность и улучшает стартовую часть электросварочного воздействия, но усиливает неравномерность в его конечной части из-за фрлуктуации импеданса. Применение ограничителей сближения электродов обеспечивает полноразмерную отработку алгоритма электросварочного воздействия при всех исследованных величинах оптимального и субкритического сжатия.

Обсуждение и перспективы дальнейших исследований. Полученные данные призваны служить основой технологических решений в создании соответствующих элементов рабочей части специализированного инструмента для формирования электросварных анастомозов. Их технологическое внедрение позволит дополнительно нарастить установленные нами преимущества электросварного межкишечного соединения над шовным. Это технологическое средство может также быть эфрфективным для повышения эфрфективности сварки других биологических тканей.
\end{abstract}

Ключевые слова: давление, ткань, электрическая сварка, анастомоз, кишка, свинья, инструмент, импеданс.

Вступ. Створення міжкишкового анастомозу (МА) методом електрозварного з'єднання є очікуваною новітньою технологією [9], що внаслідок своєї ефективності [8] покликана зменшити усталену кількість ускладнень МА [7].

Специфічна морфологічна будова стінки кишки визначає відмінність її електрофізичних характеристик (щільності, імпедансу тощо) від інших тканин [4]. У попередніх дослідженнях нами встановлено, що нерівномірність товщини та структури стінок кишок, зумовлена наявністю теній, брижових судин та прилеглих жирових клітин, спричинює нерівномірність структури електрозварного з'єднання, та, відповідно, потребу у посиленому стисненні задля гомогенізації щільності та електропровідності. Але при цьому величина стиснення $€$ близькою до руйнівної для стінки кишки [2], оскільки менші величини є неефективними [1]. Величини стиснення та радіочастотного електричного впливу на тканини кишки, з метою їх з’єднання, відрізняються поміж дослідницьких груп у кілька разів [5, 6], що вказує на незавершеність пошуку оптимального рішення, яке, вочевидь, полягає в обмеженні критичного впливу на тканину. 
Загроза руйнування шарів стінки кишки, як перед початком електрозварювання, так і впродовж нього, визначає необхідність розробки клінічних та технічних рішень, спрямованих на контрольованість механічного та електричного чинників впливу під час створення електрозварного з’єднання.

Мета дослідження: створити оптимальний засіб врівноваження та розподілу зусилля щодо стиснення тканини в моделі електрозварного МА задля досягнення цим способом стабільності відпрацьовування алгоритму високочастотного зварювання стінок кишки.

Матеріал та методи дослідження. Повноцінність відпрацювання алгоритму програмованого електрозварного впливу, залежно від засобу забезпечення рівномірності та стабільності стиснення тканин стінок кишки в моделі електрозварного МА, досліджували за зміною імпедансу цих тканин.

Як засоби досліджували конструктивні особливості електродів: пласкі електроди площею

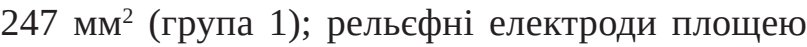


254 мм² $^{2}$ обмежувачами їх зближення (група 3). Досліджувані електроди були складовою прототипу клінічного інструменту для створення МА, який був розміщений в експериментальному електрозварювальному стенді, розробленому в Інституті електрозварювання ім. Є. О. Патона НАН України.

Матеріалом для дослідження був біоімітатор кишки людини з відповідним діаметром та товщиною стінки органу, яким слугував органокомплекс сільськогосподарської тварини - свині. Органокомплекси забирали безпосередньо на фермі після умертвіння тварин, яке було заплановане з не пов'язаних з експериментами причин та відбувалося з дотриманням вимог Закону України № 3447-IV «Про захист тварин від жорстокого поводження» та законодавства ЄС. Експерименти проводили в умовах лабораторії відділу електрозварювання живих тканин Інституту електрозварювання ім. Є. О. Патона.

Як джерело високочастотного електричного струму використовували адаптований до умов експерименту апарат ЕКВ3-300 «Патонмед» (базова робоча частота 440 кГц) конструкції та виробництва Інституту електрозварювання, дозволений до клінічного використання.

Реєстрацію значень струму і напруги в процесі експериментів та моніторинг процесу з виведенням на екран в реальному часі цих значень, а також імпедансу та вкладеної в тканину потужності, здійснювали за допомогою модуля швидкого аналого-цифрового перетворення та персонального комп’ютера.

Об’єкт дослідження охолоджували до $4{ }^{\circ} \mathrm{C}$ та протягом 6-10 год доставляли до лабораторії. У лабораторії його готували до експерименту, занурюючи у теплий $\left(26-32{ }^{\circ} \mathrm{C}\right)$ розчин 0,9\% $\mathrm{NaCl}$ на 10-20 хв до досягнення тканиною температури розчину. Температуру тканини та розчину вимірювали інфрачервоним безконтактним пірометром GM300 («Benetech»).

Біоімітатор складали вдвічі, серозними оболонками до середини, моделюючи розташування кишки в циркулярному МА, та фіксували між електродами експериментального стенду.

В серії досліджень (загальною кількістю 348 експериментів) прикладали попередньо відкаліброване навантаження ззовні до електродів, створюючи ними тиск на тканину, величину якого

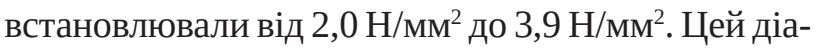
пазон був визначений нами як межі оптимальної величини стиснення всіх шарів кишки [2]. Після попереднього стиснення подавали високочастотну електричну напругу на електроди за алгоритмом, що визначався автоматично відповідно до патенту [3]. Максимальна величина напруги досягала 200 В. Показники тиску, тривалість стиснення та наведені вище базові електричні параметри були встановлені нами в попередніх дослідженнях.

Статистичну обробку отриманих даних виконували з використанням комп'ютерних програм пакету STATISTICA (StatSoft Statistica v. 10.0.). Статистичну значимість порівнюваних показників з нормальним розподілом, яка визначалося за критерієм згоди Колмогорова - Смирнова, встановлювали з використанням дисперсійного аналізу (ANOVA) та t-крітерію Ст’юдента, при рівні значущості $\mathrm{p}=0,05$. У тексті наведені репрезентативні фрагменти отриманих даних, представлені як «середнє \pm стандартне відхилення» $(\mathrm{M} \pm \mathrm{s})$.

Результати та їх обговорення. У першій серії з 88 досліджень підбирали оптимальні значення тиску між електродами в раніше визначеному

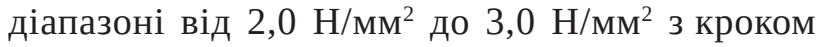
0,1 Н/мм² у спробі знайти точку рівноваги стиснення та резистентності тканини, в якій буде досягнута стабільність форми кривої зміни імпедансу, закладеної як цільова до алгоритму електрозварного впливу для створення МА. Для досліджень використовували напругу в діапазоні від 80 В до 180 В. Нижні значення величини напруги були вибрані 


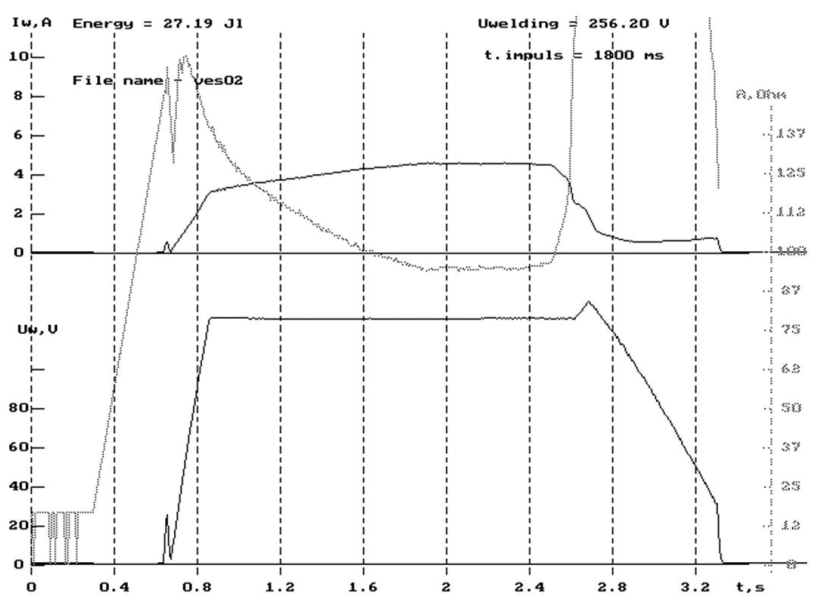

A)



Б)

Рис. 1. Порівняно більш плавна зміна імпедансу при електрозварному з'єднанні стінок тонкої кишки при використанні східцеподібних рельєфних (1Б) поверхонь електродів, порівняно з пласкими (1А)

в ході попередніх експериментів як порогові для настання різкої зміни електричних параметрів тканини (критична напруга), що є необхідною умовою для створення електрозварного з'єднання тканин стінки кишки.

В ході експериментів в цій групі під час перебігу електрозварного імпульсу спостерігали коливання імпедансу, що значно відхилялися від його цільової кривої. Проявами таких коливань у 7,5\% спостережень було недосягнення первинних базових параметрів зниження імпедансу, внаслідок чого не відбувся перехід до чергової фази алгоритму. У 42,5\% зміна імпедансу відбувалася зі значним відхиленням швидкості його зростання. Також не завжди відбувалося вчасне переривання алгоритму, що означало збереження занизького рівня імпедансу в тканині внаслідок надмірного зближення електродів. При спробі змінити закладений коридор відхилення імпедансу значно посилились розбіжності у рівномірності та міцності з’єднання. На додачу, у 7,5\% досліджень спостерігали раптове зниження імпедансу нижче визначеної межі і переривання подавання напруги. Цільову форму зміни імпедансу в групі 1 отримали у 42,5\% досліджень.

В групі 2 досліджували вплив запобігання можливого зміщення електродів в горизонтальній площині та створення вузької лінії рівномірного стиснення в 80 пробах з рельєфними електродами площею 280 мм². Випробовували застосування різних конфігурацій рельєфу електродів (східцеподібні, навскісні), зміну амплітуди електричної напруги в межах від 50 В до 200 В, ефективність зміни значень закладених до алгоритму формування електрозварювального імпульсу коефіцієнтів, величину прикладеного до них зовнішнього тиску

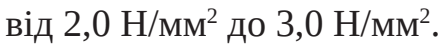

В цій серії досліджень електропровідність тканин кишки між електродами суттєво підвищилася порівняно з попередньою серією експериментів (рис. 1). Критична напруга знизилась від 80 В до 70 В відповідно. Зросла частота досягнення первинних базових параметрів зниження імпедансу тканин до 82,5\%, але в наступній фазі алгоритму раптове зниження імпедансу нижче визначеної межі з перериванням подавання напруги спостерігали у 30\% досліджень. У ній же, подібно до групи 1, у 32,5\% проб впродовж відпрацювання електрозварного алгоритму відбувалися значні коливання імпедансу, що виходило за цільові межі коливання. Нерівномірність нелінійно посилювалася у поєднанні з гостротою форми електродів, підвищенням тиску між електродами та максимальною електричною напругою.

В 180 дослідженнях групи 3 визначали вплив обмеження можливості стискання стінок кишки між електродами в вертикальній площині та надмірного зближення електродів. Досліджували обмеження зближення електродів на певну відстань в діапазоні від 0,03 мм до 0,3 мм. Цю відстань забезпечували введенням конструктивних елементів до електродної частини інструменту.

Застосування обмежувачів зближення електродів виявилося найефективнішим при співвідношенні висоти обмежувача до товщини тканин між електродами в моделі МА як 1:40. При цьому гарантовано відбувалося повнотривале відпрацювання 
алгоритму електрозварного впливу, побудованого на основі контрольованої плавної двофазної зміни імпедансу тканин кишки між електродами, навіть при контрольному прикладенні тиску на електроди 3,9 H/Mм².

Ефективність з’єднання при цьому залежала від досягнення базової електропровідності на підготовчій (імпульсній) фазі з'єднання та величини прикладеної електричної напруги. Раптове зниження імпедансу нижче визначеної межі і переривання подавання напруги спостерігали лише у 2,5\% досліджень. Впродовж відпрацювання електрозварного алгоритму значні коливання імпедансу, що виходили за цільові межі коливання, відбувалися лише у 15\% спостережень - коли співвідношення висоти обмежувача до товщини тканин між електродами в моделі МА було меншим за 1:40, що підтверджувало ефективність цього способу.

\section{Висновки.}

1. Зменшення тиску електродів на тканину спричинює та посилює до межі неефективності впливу коливання / відхилення величини імпедансу в процесі встановлення стабільної форми кривої зміни імпедансу, закладеної як цільова до алгоритму електрозварного впливу для створення МА.

\section{Література.}

1. Встановлення первинних вимог до експериментальних засобів дослідження та умов створення електрозварного з'єднання стінок кишечнику / С. С. Подпрятов, С. Є. Подпрятов, А. В. Макаров [та ін.] // Шпитальна хірургія. Журнал імені Л. Я. Ковальчука. — 2018. — № 2. - С. 56-60.

2. Модельне експериментальне дослідження механічної резистентності стінки кишки людини під тиском в прототипі електрозварювального інструменту / С. С. Подпрятов, С. Є. Подпрятов, Г. С. Маринський [та ін.] // Проблеми військової охорони здоров'я. 2017. — № 2. — С. 325-331.

3. Пат. України 106513. Спосіб з’єднання зварюванням біологічних тканин людей і тварин з використанням високочастотного струму / Б. Є. Патон, В. А. Ткаченко, Г. С. Маринський [та ін.]. — № a2012 09185 Заявл. 26.07.2012, Опубл. 10.09.2014, Бюл. № 17.

4. A new combined high-frequency ultrasound-impedance planimetry measuring system for the quantification of organ wall biomechanics in vivo / C. S. Jørgensen, F. H. Dall, S. L. Jensen, H. Gregersen // Int. Wound. J. - 2013. - Vol. 10, No. 4. - P. 411-417.

5. Bipolar radiofrequency-induced thermofusion of intestinal anastomoses - feasibility of a new anastomosis technique in porcine and rat colon /
2. Застосування рельєфної форми електродів підвищує електропровідність об’єкту зварювання і покращує стартову частину перебігу алгоритму електрозварного впливу, але посилює нерівномірність в його кінцевій частині через флуктуацію імпедансу аж до раннього переривання подавання напруги внаслідок падіння імпедансу (короткого замикання).

3. Застосування обмежувачів зближення електродів забезпечує повнотривале відпрацювання алгоритму електрозварного впливу, побудованого на основі контрольованої плавної двофазної зміни імпедансу тканин кишки між електродами, за всіх досліджених величин оптимального та субкритичного стиснення.

\section{Обговорення та перспективи подальших}

досліджень. Отримані дані покликані слугувати основою технологічних рішень у створенні відповідних елементів робочої частини спеціалізованого інструменту для формування електрозварних МА. Ïх технологічне впровадження надасть можливість додатково наростити встановлені переваги електрозварного міжкишкового з'єднання над шовним. Цей технологічний засіб може також бути ефективним для підвищення ефективності зварювання інших біологічних тканин.

C. Holmer, H. Winter, M. Kröger [et al.] / Langenbecks Arch. Surg. — 2011. — Vol. 396, No. 4. — P. 529-533.

6. Colorectal anastomosis facilitated by the use of the LigaSure ${ }^{\circledR}$ sealing device: comparative study in an animal model / F. Sánchez-De Pedro, C. Moreno-Sanz, A. Morandeira-Rivas [et al.] // Surg. Endosc. - 2014. — Vol. 28, No. 2. - P. 508-514.

7. Colorectal anastomotic healing: why the biological processes that lead to anastomotic leakage should be revealed prior to conducting intervention studies / J. W. Bosmans, A. C. Jongen, N. D. Bouvy, J. P. Derikx // BMC Gastroenterol. — 2015. — Vol. 15, No. 1. — P. 180.

8. Comparison of a new high-frequency electric welding system for intestinal closure with hand-sewn in vivo pig model / S. Han, Z. Cai, X. Ning [et al.] // J. Laparoendosc. Adv. Surg. Tech. A. - 2015. Vol. 25, No. 8. - P. 662-667.

9. Ho Y. H. Techniques for colorectal anastomosis / Y. H. Ho, M. A. T. Ashour // World Journal of Gastroenterology. — 2010. — Vol. 16, No. 13. P. 1610-1621. 


\section{References.}

1. Podpriatov, S. S., Podpryatov, S. E., Makarov, A. V., Marinsky, G. S., Tkachenko, V. A., Chernets, O. V., ... \& Lopatkina, K. G. (2018). Vstanovlennya pervinnikh vimog do eksperimental'nikh zasobiv doslidzhennya ta umov stvorennya elektrozvarnogo z'ednannya stinok kishechniku [Establishing the first requirements in experimental equipment for investigations and creation conditions of electric welding intestinal connection]. Shpital'na khirurgiya (Hospital Surgery). Journal named by L. Ya. Kovalchuk, 2, 56-60. doi 10.11603/24144533.2018.2.9230. [In Ukrainian].

2. Podpriatov, S.S., Podpryatov, S. E., Marinsky, G. S., Chernets, O. V., Tkachenko, V. A., Bielousov, I. O., ... Serdyuk, V. K. (2017). Modelne eksperymentalne doslidzhennya mekhanichnoyi rezystentnosti stinky kyshky lyudyny pid tyskom v prototypi elektrozvaryuvalnoho instrumentu [Model experimental research of human intestine walls mechanical resistance under the pressure inside biologic welding instrument prototype]. Problemy viyskovoyi okhorony zdorovya (Problems of military health). 2, 325-331. [In Ukrainian].

3. Paton, B. E., Tkachenko, V. A., Marins'kii, G. S., Podpryatov, S. E., Chernets', O. V., Chvertko, N. A., ... \& Matviichuk, G. M. (2014). Sposib z'ednannya zvaryuvannyam biologichnikh tkanin lyudei i tvarin z vikoristannyam visokochastotnogo strumu [The method of connecting the welding of biological tissues of people and animals using high-frequency current]. Ukraine Patent No. 106513. Bul. No. 17. [In Ukrainian].

4. Jørgensen, C. S., Dall, F. H., Jensen, S. L. \& Gregersen, H. (2013). A new combined high-frequency ultrasoundimpedance planimetry measuring system for the quantification of organ wall biomechanics in vivo. Int. Wound J., 10(4), 411-417. doi: 10.1016/00219290(95)95275-A.
5. Holmer, C., Winter, H., Kröger, M., Nagel, A., Jaenice, A., Lauster, R., ... \& Ritz, J.P. (2011). Bipolar radiofrequency-induced thermofusion of intestinal anastomoses - feasibility of a new anastomosis technique in porcine and rat colon. Langenbecks Arch. Surg., 396(4), 529-533. doi: 10.1007/s00423-011-07560 .

6. Sánchez-De Pedro, F., Moreno-Sanz, C., MorandeiraRivas, A., Tenías-Burillo, J. M., \& Alhambra-Rodríguez De Guzmán, Cr. (2014). Colorectal anastomosis facilitated by the use of the LigaSure ${ }^{\circledR}$ sealing device: comparative study in an animal model. Surg. Endosc., 28(2), 508-514. doi: 10.1007/s00464-013-3194-y.

7. Bosmans, J. W., Jongen, A. C., Bouvy, N. D., \& Derikx, J. P. (2015). Colorectal anastomotic healing: why the biological processes that lead to anastomotic leakage should be revealed prior to conducting intervention studies. BMC Gastroenterology, 15(1), 180. doi: 10.1186/s12876-015-0410-3.

8. Han, S., Cai, Z., Ning, X., He, L., Chen, J., Huang, Z., ... Li, Z. (2015). Comparison of a new high-frequency electric welding system for intestinal closure with handsewn in vivo pig model. J. Laparoendosc. Adv. Surg. Tech. A, 25(8), 662-667. doi: 10.1089/lap.2015.0101.

9. Ho, Y.-H., \& Ashour, M. A. T. (2010). Techniques for colorectal anastomosis. World Journal of Gastroenterology, 16(13), 1610-1621. doi.org/10.3748/ wjg.v16.i13.1610. 